\title{
Novel Structure, Properties and Inactivation of Glutamine Synthetase Cloned from Bacteroides fragilis
}

\author{
By JAMES A. SOUTHERN, ${ }^{2}$ JOAN R. PARKER ${ }^{2}$ AND \\ DAVID R. WOODS ${ }^{2 *}$ \\ ${ }^{1}$ State Vaccine Institute, Alexandra Road, Pinelands 7405, South Africa \\ ${ }^{2}$ Department of Microbiology, University of Cape Town, Rondebosch 7700, South Africa
}

(Received 9 February 1987; revised 24 April 1987)

\begin{abstract}
The cloned Bacteroides fragilis glutamine synthetase (GS) subunit produced in Escherichia coli had the same apparent $M_{\mathrm{r}}$ of approximately 75000 as the GS subunit from $B$. fragilis cells. The $B$. fragilis GS enzyme had an apparent $M_{\mathrm{r}}$ of approximately 490000 and it is concluded that the GS is a hexamer. The cloned GS did not appear to be regulated by adenylylation and deadenylylation and the cloned enzyme was inactivated by snake venom phosphodiesterase. The $\mathrm{pH}$ profiles of the cloned GS, assayed by the $\gamma$-glutamyl transferase (GGT) assay were similar for $\mathrm{NH}_{4}^{+}$-shocked and unshocked cell extracts and an isoactivity point was not obtained from these curves. The cloned GS was subject to feedback inhibition by amino acids but not by AMP. The GGT activity of the cloned GS in $\mathrm{NH}_{4}^{+}$-shocked and unshocked cell-free extracts was inhibited by $\mathrm{Mg}^{2+}$. $\mathrm{Mn}^{2+}$ stimulated the cloned GS GGT activity of $\mathrm{NH}_{4}^{+}$-shocked cell-free extracts. Western blotting indicated that GS production was regulated by nitrogen in $B$. fragilis cells but cell extracts showed no GGT activity. Cloned $B$. fragilis GS produced in $E$. coli was specifically and irreversibly inactivated by $B$. fragilis cell extracts.
\end{abstract}

\section{INTRODUCTION}

Glutamine synthetase (GS) (EC 6.3 .1 .2) plays a central role in nitrogen metabolism and the assimilation of ammonia in many prokaryotes, eukaryotes and archaebacteria. GS enzymes of eukaryotic origin are octamers (Prusiner \& Stadtman, 1973) whereas the GS enzymes of eubacteria and an archaebacterium have been shown to be dodecamers with an $M_{\mathrm{r}}$ of about 600000 composed of a single type of subunit whose $M_{\mathrm{r}}$ falls in the range $44000-59000$ (Streicher \& Tyler, 1980; Bhatnagar et al., 1986). We recently reported that a cloned Bacteroides fragilis GS had an apparent subunit $M_{\mathrm{r}}$ of approximately 75000 which is markedly larger than other bacterial GS subunits (Southern et al., 1986). In view of the large $M_{\mathrm{r}}$ of the $B$. fragilis GS subunit we investigated the $M_{\mathrm{r}}$, structure and properties of the GS enzyme.

Yamamoto et al. (1984) investigated the pathway of ammonia assimilation in $B$. fragilis and concluded that GS may not be important for ammonia incorporation into amino acids. They were unable to detect GS activity in $B$. fragilis cell extracts by the $\gamma$-glutamyl transferase (GGT) assay. In contrast, we recently reported that the $B$. fragilis GS cloned in Escherichia coli is active in the GGT assay (Southern et al., 1986). We investigated the specific inhibition of $B$. fragilis GS by $B$. fragilis cell extracts and utilized the product of the cloned $B$. fragilis gene to examine the presence of GS in $B$. fragilis by Western blotting.

\footnotetext{
Abbreviations: GGT, $\gamma$-glutamyl transferase; GS, glutamine synthetase; SVP, snake venom phosphodiesterase I.
} 


\section{MATERIALS AND METHODS}

Bacterial strains, plasmids, media and growth conditions. B. fragilis strain $\mathrm{Bf}-1$ was described by Mossie et al. (1979). Plasmid pJS139 [ $g \ln A^{+}$, ampicillin resistant $\left(\mathrm{Ap}^{\mathrm{r}}\right)$ ], is an $E$. coli recombinant plasmid which contains a B. fragilis $\mathrm{Bf}-1 \mathrm{~g} \ln A$ gene and enables $E$. coligln $A$ deletion mutants to utilize $\left(\mathrm{NH}_{4}\right)_{2} \mathrm{SO}_{4}$ as a sole source of nitrogen (Southern et al., 1986). E. coli YMC-10 gln $A^{+} n t r B^{+} n t r C^{+}$and E. coli YMC-11 glnAntrBntrC were described by Backman et al. (1981).

B. fragilis was grown under anaerobic conditions in a complex medium which contained $\left(1^{-1}\right)$ : Difco tryptic soy broth, $24 \mathrm{~g}$; Difco yeast extract, $10 \mathrm{~g}$; glucose, $1 \mathrm{~g}$; L-cysteine hydrochloride, $0.5 \mathrm{~g}$; haemin, $5 \mathrm{mg}$; and menadione, $0.5 \mathrm{mg}$ (Southern et al., 1984). Growth under nitrogen-limiting conditions was achieved by incubation for $2 \mathrm{~h}$ following the addition of an equal volume of $0.01 \mathrm{M}$-potassium phosphate buffer $\mathrm{pH} 7 \cdot 4$, containing $0 \cdot 15 \mathrm{M}-\mathrm{NaCl}$ and $2 \mathrm{~g}$ glucose $1^{-1}$ to late exponential phase $B$. fragilis cultures growing in the complex medium. Alternatively brain heart infusion broth (Holdeman \& Moore, 1972) cultures were diluted (1:40) into minimal medium (Varel \& Bryant, 1974) which was nitrogen-free or contained $0.3 \mathrm{mM}-\left(\mathrm{NH}_{4}\right)_{2} \mathrm{SO}_{4}$ and reincubated until the cultures reached an $\mathrm{OD}_{600}$ value of 0.2 .

After incubation at $37^{\circ} \mathrm{C}$ the stabilizer of glutamine synthetase (GS), $N$-cetyl- $N, N, N$-trimethylammonium bromide (CTAB) $\left(0.1 \mathrm{mg} \mathrm{ml}^{-1}\right.$, Merck), was added to the cultures and incubation was continued for $10 \mathrm{~min}$. The cells were collected by centrifugation and resuspended to $1 \%(\mathrm{v} / \mathrm{v})$ of the original culture volume in extraction buffer $(10 \mathrm{~mm}$-imidazole $/ \mathrm{HCl} \mathrm{pH} 7 \cdot 1,100 \mathrm{~mm}-\mathrm{KCl})$ and disrupted by sonication. After centrifugation the supernatant was kept at $-70^{\circ} \mathrm{C}$. The $E$. coli strains were grown in LB (Luria-Bertani) medium (Davis et al., 1980) or in CSH (Cold Spring Harbor) glucose minimal medium (Miller, 1972) supplemented as described in the text. Nitrogen-limiting conditions were achieved by the addition of an equal volume of nitrogen-free CSH minimal medium to late exponential CSH minimal medium cultures. After incubation CTAB was added and the cells were disrupted as described above. For ammonia-shocked cells, $15 \mathrm{~mm}-\left(\mathrm{NH}_{4}\right)_{2} \mathrm{SO}_{4}$ was added $5 \mathrm{~min}$ before the addition of CTAB.

GS assay. GS activity was assayed in crude cell extracts by the $\gamma$-glutamyl transferase (GGT) and forward transferase assays (Bender et al., 1977). Specific enzyme activity is expressed as $\mu \mathrm{mol} \gamma$-glutamyl hydroxamate formed (mg protein) $)^{-1} \mathrm{~min}^{-1}$.

Protein was determined using the dye-binding method of Bradford (1976).

Purification of GS. GS was extracted and purified from B. fragilis and $E$. coli YMC-11(pJS139) by differential polyethylene glycol (PEG) precipitation and gel filtration as described by Southern et al. (1986). Purified $B$. fragilis GS from $E$. coli YMC-11(pJS139) was stained with sodium phosphotungstate and examined in an electron microscope.

$M_{r}$ determinations. The $M_{\mathrm{r}}$ of the purified $B$. fragilis GS holoenzyme was determined by Sephacryl S-400 (Pharmacia) column chromatography and pore gradient electrophoresis. A Sephacryl S-400 column $(10 \times 400 \mathrm{~mm})$ was equilibrated and eluted with column buffer $(1 \%$, w/v, $\mathrm{KCl}, 10 \mathrm{~mm}$-imidazole/ $\mathrm{HCl} \mathrm{pH} 7 \cdot 15)$ at $0.1 \mathrm{ml} \mathrm{min} \mathrm{m}^{-1}$ at $4{ }^{\circ} \mathrm{C}$. Pore gradient electrophoresis was done in a $4-30 \%(\mathrm{w} / \mathrm{v})$ nondenaturing polyacrylamide gradient according to the manufacturer's instructions (Pharmacia). The electrophoresis buffer was $0.09 \mathrm{M}$ Tris/borate/EDTA (2mM), pH 8.5. After electrophoresis the gel was divided in half and one half was stained with Coomassie brilliant blue. The other half was cut into $3 \mathrm{~mm}$ slices and assayed for GS activity. The $M_{\mathrm{r}}$ of the GS subunits was determined by SDS-PAGE (Laemmli, 1970; O'Farrel, 1985; Southern et al., 1986).

Western blotting. Polypeptides resolved by SDS-PAGE $(8 \%, w / v$, acrylamide $)$ were electroblotted onto nitrocellulose membranes (Towbin et al., 1979). The membranes were blocked with $10 \mathrm{~mm}-\mathrm{Tris} / \mathrm{HCl} \mathrm{pH} \mathrm{7.4,}$ $0.15 \mathrm{M}-\mathrm{NaCl}, 2 \%(\mathrm{w} / \mathrm{v})$ nonfat dried milk (Johnson et al., 1984) and $0.05 \%(\mathrm{v} / \mathrm{v})$ Tween 20 at room temperature for $18 \mathrm{~h}$. B. fragilis GS antiserum was adsorbed with a sonicated cell extract of $E$. coli YMC-11 to remove non-specific E. coli antibodies. B. fragilis GS antibody binding (Southern et al., 1986) and the development of bands using a goat anti-rabbit serum conjugated to horseradish peroxidase were done as described by Rybicki \& von Wechmar (1982), except that Tween 20 was used in place of NP-40.

SVP treatment of GS. Cloned GS extracts were incubated at $37^{\circ} \mathrm{C}$ with $0.5 \mathrm{mg}$ snake venom phosphodiesterase I (SVP) $\mathrm{ml}^{-1}$, sampled at various time intervals and immediately frozen at $-70^{\circ} \mathrm{C}$. All the samples were assayed with and without $0.25 \mathrm{mM}-\mathrm{Mn}^{2+}$.

Inhibition of cloned GS by B. fragilis cell extracts. $B$. fragilis cells were collected by centrifugation, washed and resuspended in $0.01 \mathrm{M}-\mathrm{Tris} / \mathrm{HCl} \mathrm{pH} \mathrm{7.9}$, followed by disruption by sonication. After centrifugation the supernatant was added to crude samples of the cloned $B$. fragilis GS.

\section{RESULTS}

\section{$M_{r}$ of $B$. fragilis $G S$}

The cloned $B$. fragilis GS was shown to have an apparent subunit $M_{\mathrm{r}}$ of approximately 75000 (Southern et al., 1986). The $M_{\mathrm{r}}$ of the purified $B$. fragilis GS holoenzyme produced by pJS139 in 
the $E$. coli $\mathrm{YMC}^{-11} \mathrm{G} \ln \mathrm{A}^{-} \mathrm{NtrB}^{-} \mathrm{NtrC}^{-}$deletion strain was determined by Sephacryl $\mathrm{S}-400$ column chromatography (Fig. 1) and by pore gradient electrophoresis (Fig. 2). Both methods indicated that the cloned $B$. fragilis GS holoenzyme had an apparent $M_{\mathrm{r}}$ of approximately 490000. The fraction from the S-400 column with an apparent $M_{\mathrm{r}}$ of approximately 490000 showed GS activity (Fig. 1). This fraction gave a single band on pore gradient electrophoresis with an apparent $M_{\mathrm{r}}$ of approximately 490000 (Fig. 2). It was not possible to demonstrate GS activity in crushed $3 \mathrm{~mm}$ gel slices by the GGT assay.

Electron microscopy of negatively stained, purified, cloned $B$. fragilis GS revealed molecules with a central hole and hexagonal shape (data not shown). These features are characteristic of GS enzymes from other bacteria (Frey et al., 1975). However, tetragonal structures, which are indicative of side views of double-layered ring structures, were not observed.

\section{Properties of the cloned B. fragilis GS}

Crude cell extracts of E. coli YMC-11(pJS139) from $\mathrm{NH}_{4}^{+}$-shocked and unshocked cultures were assayed for GGT activity between $\mathrm{pH} 6.0$ and $\mathrm{pH} 8.0$ (Fig. 3). $\mathrm{NH}_{4}^{+}$-shocking caused a reduction in GGT activity. This decrease in activity was not due to an effect of $\mathrm{pH}$ and the $\mathrm{pH}$ profiles for GGT activity were similar for the shocked and unshocked cell extracts. The optimum $\mathrm{pH}$ for GGT activity for both crude extracts was between $\mathrm{pH} 6.5$ and 7.0. No GS isoactivity point was demonstrated. The optimum temperature for activity of the cloned GS in the GGT assay was $45^{\circ} \mathrm{C}$. The activity of the cloned $B$. fragilis GS in crude extracts from $E$. coli YMC-11(pJS139) was confirmed by the forward transferase assay.

The effect of feedback modifiers on the cloned $B$. fragilis GS was determined in crude extracts prepared from $E$. coli YMC-11(pJS139) cells grown under nitrogen-limiting conditions (Table 1). Glutamine, which is a substrate for the GGT assay, did not inhibit the GGT activity of the GS whereas the other amino acids tested and $\left(\mathrm{NH}_{4}\right)_{2} \mathrm{SO}_{4}$ inhibited the GGT activity to varying extents. AMP did not inhibit GGT activity. L-Methionine-DL-sulphoximine, a glutamate analogue and noncompetitive inhibitor of GS in many bacteria (Meister, 1980) caused a $92 \%$ reduction in the GGT activity of the GS.

The effect of $\mathrm{Mn}^{2+}$ and $\mathrm{Mg}^{2+}$ on the GGT activity of crude extracts of cloned B. fragilis GS from $\mathrm{NH}_{4}^{+}$-shocked and unshocked $E$. coli YMC-11(pJS139) cells was determined (Fig. 4). The addition of $0.25 \mathrm{mM}-\mathrm{MnCl}_{2}$ to extracts from $\mathrm{NH}_{4}^{+}$-shocked cells markedly increased the GGT activity, but had no effect on the GGT activity of GS from unshocked cells. At $0.5 \mathrm{~mm}-\mathrm{MnCl}_{2}$ the GS from shocked and unshocked cells had the same GGT activity which was similar to that when no $\mathrm{MnCl}_{2}$ was added. $\mathrm{MnCl}_{2}$ concentrations $>0.5 \mathrm{mM}$ inhibited the GGT activity of GS from shocked and unshocked cells to the same extent. The GGT activity of extracts of GS from shocked and unshocked cells was inhibited by concentrations of $\mathrm{MgCl}_{2}>0.5 \mathrm{~mm}$ (Fig. 4).

\section{SVP digestion}

Since the GGT activity of cloned GS extracts from $\mathrm{NH}_{4}^{+}$-shocked and unshocked cells was affected differently by $0.25 \mathrm{mM}-\mathrm{MnCl}_{2}$, the effect of SVP on GS cell extracts was assayed in the presence or absence of $0.25 \mathrm{mM}-\mathrm{MnCl}_{2}$ (Fig. 5). Treatment of cloned GS extracts from shocked and unshocked cells with SVP inhibited the GGT activity in the presence or absence of $0.25 \mathrm{~mm}$ $\mathrm{MnCl}_{2}$. Similar results were obtained when SVP-treated extracts were assayed in the presence or absence of $10 \mathrm{mM}-\mathrm{MgCl}_{2}$ (data not shown). Control extracts incubated for $20 \mathrm{~min}$ without SVP treatment showed no decrease in activity.

\section{Detection of $G S$ in $B$. fragilis cells by Western blotting}

Western blotting with antiserum raised against the purified, cloned $B$. fragilis GS from $E$. coli cells showed that $B$. fragilis cells contained a polypeptide with the same $M_{\mathrm{r}}$ as the subunit of the purified, cloned GS ( $M_{r}$ approximately 75000 ) (Fig. 6). Production of the GS subunit was induced by growth of $B$. fragilis cells in nitrogen-limited medium (Fig. $6 b$ ). SDS-PAGE fractionated proteins from $E$. coli $\mathrm{YMC}^{-10} \mathrm{Gln} \mathrm{A}^{+} \mathrm{NtrB}^{+} \mathrm{NtrC}^{+}$and $E$. coli $\mathrm{YMC}-11$ $\mathrm{Gln}^{-} \mathrm{NtrB}^{-} \mathrm{NtrC}^{-}$cells did not react with the $B$. fragilis $\mathrm{GS}$ antiserum (Fig. 7). The weak cross-reactivity, which is sometimes observed (Southern et al., 1986), was not detected. A strong 

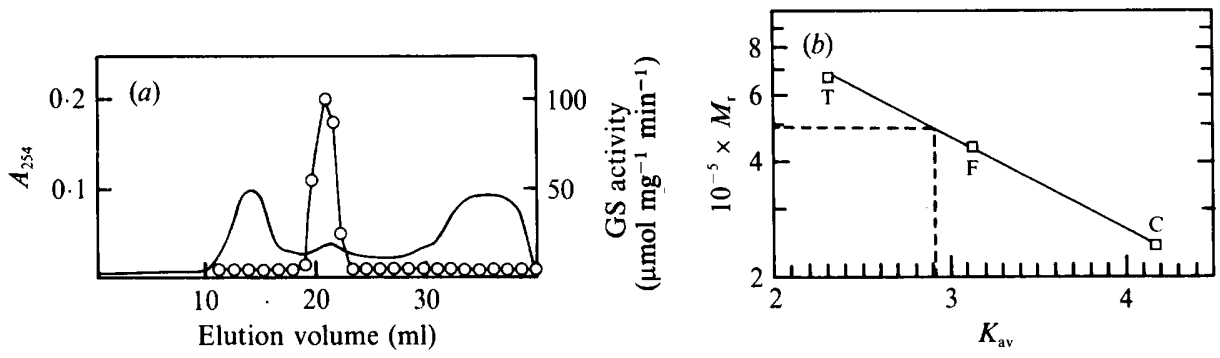

Fig. 1. Sephacryl S-400 column chromatography of the cloned B. fragilis GS from $E$. coli cells. (a) Elution profile of GS sample after precipitation by $6 \%$ (w/v) PEG. $\bigcirc$, GGT activity; -, $A_{254}$. (b) $M_{\mathrm{r}}$ determination of GS holoenzyme. $M_{\mathrm{r}}$ markers: thyroglobulin, 670000 (T); ferritin, 440000 (F); catalase, 232000 (C). The $K_{\mathrm{av}}$ of the GS is indicated by the dotted lines.

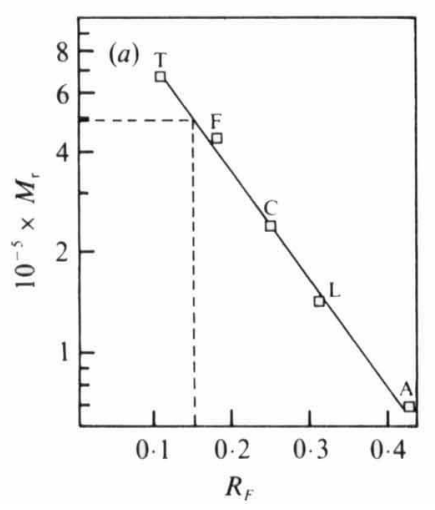

Fig. 2

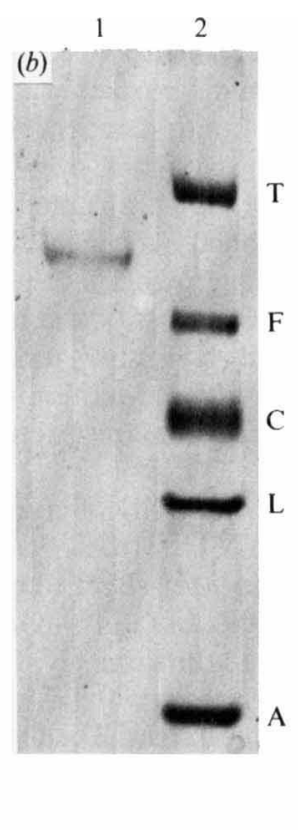

Fig. 2. Pore gradient electrophoresis of the purified, cloned $B$. fragilis GS from $E$. coli cells. The gel contained a $4-30 \%(w / v)$ polyacrylamide gradient and was $0.5 \mathrm{~mm}$ thick. After electrophoresis as described in Methods it was stained with Coomassie brilliant blue. $(a) M_{\mathrm{r}}$ determination. $M_{\mathrm{r}}$ markers : thyroglobulin, $670000(\mathrm{~T})$; ferritin, $440000(\mathrm{~F})$; catalase, $232000(\mathrm{C})$; lactic dehydrogenase, $140000(\mathrm{~L})$; bovine albumin, 67000 (A). The $R_{F}$ of the GS is indicated by the dotted line. (b) Stained gel. Lane 1, purified GS after S-400 column chromatography $(5 \mu \mathrm{g})$; lane 2, $M_{\mathrm{r}}$ markers.

Fig. 3. Effect of $\mathrm{pH}$ on GGT activity in extracts from $\mathrm{NH}_{4}^{+}$-shocked $(\mathrm{O})$ and unshocked (O) E. coli YMC-11(pJS139) cells. GGT activity is expressed as $\mu$ mol $\gamma$-glutamyl hydroxamate formed (mg protein) $)^{-1} \min ^{-1}$. The SEM values were $5-10 \%$ of the values in the Figure.

reaction with the $B$. fragilis GS antiserum was detected in SDS-PAGE fractionated proteins from $E$. coli YMC-11(pJS139) cells. Treatment of the Western blot with antiserum to Vibrio alginolyticus GS, which cross-reacts with $E$. coli GS (Maharaj et al., 1986), revealed the $E$. coli GS subunit in SDS-PAGE fractionated proteins from E. coli YMC-10. 
Table 1. Effect of feedback modifiers on cell-free activity of the cloned B. fragilis GS

The final concentrations of the modifiers added to the assay mixture were as shown. GGT activities are expressed as a percentage of the activity of the extract without added modifier [ $2.4 \mu \mathrm{mol} \gamma$-glutamyl hydroxamate formed (mg protein) $)^{-1} \mathrm{~min}^{-1}$ ]. SEM values were $5-10 \%$ of the values in the Table.

\begin{tabular}{lcc}
\multicolumn{1}{c}{ Modifier } & $\begin{array}{c}\text { Modifier concn } \\
(\mathrm{mM})\end{array}$ & $\begin{array}{c}\text { GGT activity } \\
(\%)\end{array}$ \\
L-Glutamine & 50 & 110 \\
AMP & 20 & 104 \\
L-Proline & 50 & 89 \\
L-Isoleucine & 50 & 86 \\
(NH $\left._{4}\right)_{2} \mathrm{SO}_{4}$ & 50 & 82 \\
L-Glycine & 50 & 74 \\
L-Glutamic acid & 50 & 70 \\
L-Alanine & 50 & 68 \\
L-Histidine & 50 & 46 \\
L-Arginine & 50 & 38 \\
L-Methionine-DL-sulphoximine & $0 \cdot 1$ & 8
\end{tabular}
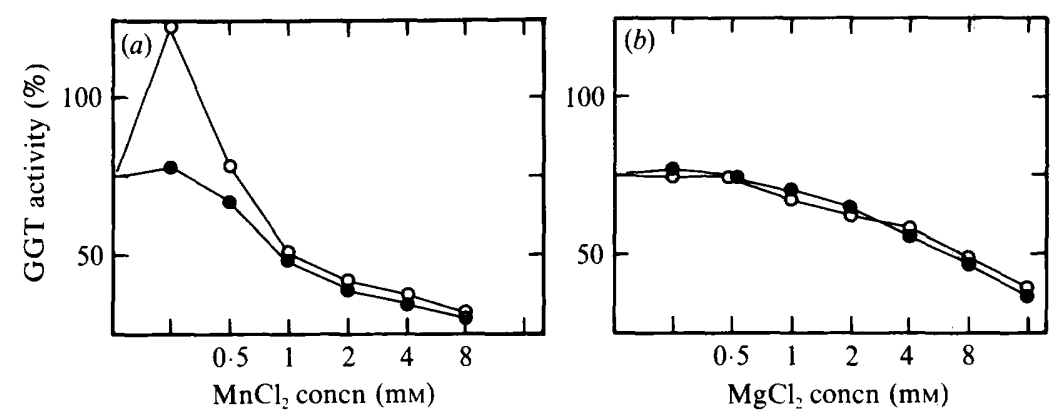

Fig. 4. Effect of $\mathrm{Mn}^{2+}$ and $\mathrm{Mg}^{2+}$ on the GGT activity of crude extracts of cloned B. fragilis GS from $\mathrm{NH}_{4}^{+}$-shocked $(\mathrm{O})$ and unshocked $(O)$ E. coli YMC-11(pJS139) cells. (a) GGT activity determined in the presence of $\mathrm{MnCl}_{2}$. (b) GGT activity determined in the presence of $\mathrm{MgCl}_{2}$. The results are expressed as a percentage of the GGT activity in cell extracts without added $\mathrm{MnCl}_{2}$ or $\mathrm{MgCl}_{2}$ respectively [1.00 and $0.76 \mu \mathrm{mol} \gamma$-glutamyl hydroxamate formed (mg protein) ${ }^{-1} \mathrm{~min}^{-1}$ respectively for shocked and unshocked cells]. The SEM values were $5-10 \%$ of the values in the Figure.
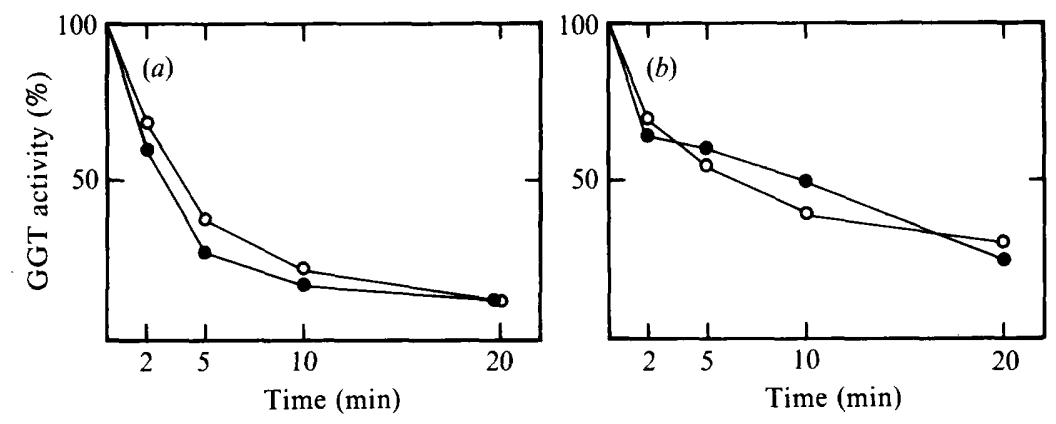

Fig. 5. The effect of length of SVP treatment on GGT activity of crude extracts of cloned $B$. fragilis GS from $\mathrm{NH}_{4}^{+}$-shocked and unshocked $E$. coli YMC-11(pJS139) cells. (a) $\mathrm{NH}_{4}^{+}$-shocked extracts assayed in the presence $(O)$ or absence $(O)$ of $\mathrm{MnCl}_{2}$. (b) Unshocked extracts assayed in the presence $(O)$ or absence (O) of $\mathrm{MnCl}_{2}$. The results are expressed as a percentage of the activity of the starting material (see Fig. 4 for absolute values). The SEM values were $5-10 \%$ of the values in the Figure. 


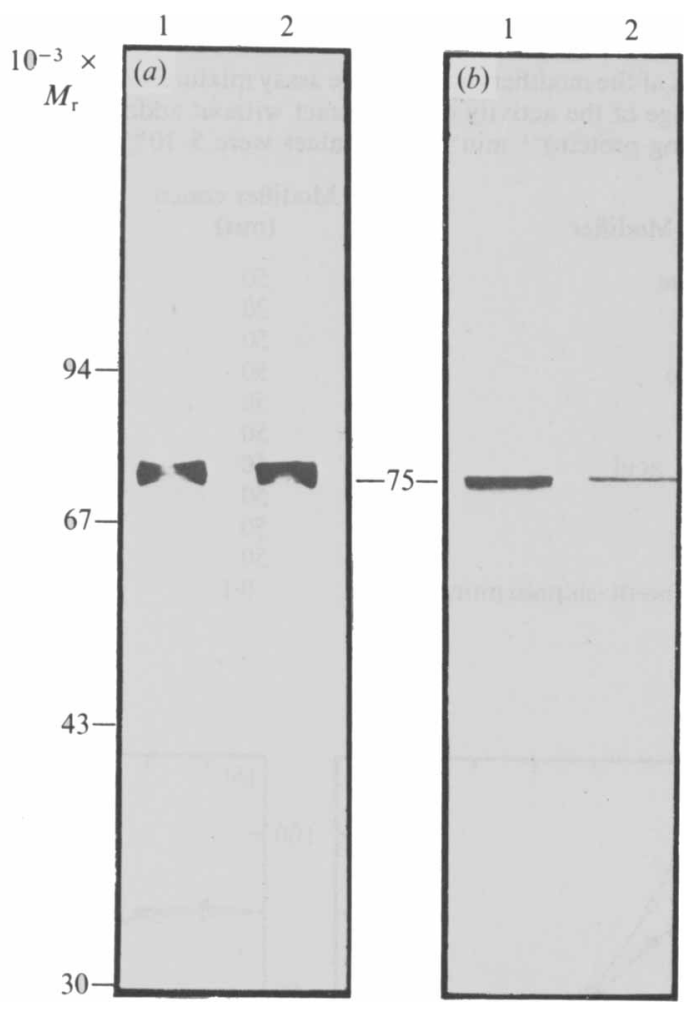

Fig. 6. Western blots of purified, cloned GS and crude extracts from E. coli YMC-11(pJS139) and B. fragilis cells. (a) E. coli YMC-11(pJS139): lane 1, crude extract (5 $\mu$ g protein); lane 2, purified GS (5 $\mu \mathrm{g}$ protein). (b) B. fragilis crude extracts from nitrogen-limited (lane $1,50 \mu \mathrm{g}$ protein) and nitrogenrepressed (lane $2,50 \mu \mathrm{g}$ protein) cultures.

\section{Immunoprecipitation of the cloned B. fragilis $G S$ from $E$. coli}

A partially purified preparation of the cloned $B$. fragilis GS from $E$. coli was assayed before and after immunoprecipitation with the antiserum. Total loss of GGT activity was observed after immunoprecipitation. The immunoprecipitate and supernatant lacking GS activity were fractionated by SDS-PAGE. The presence of the $M_{\mathrm{r}} 75000$ GS polypeptide was demonstrated by Western blotting in the purified GS preparation before immunoprecipitation and in the immunoprecipitate, but this band was absent in the supernatant (Fig. 8). The non-specific bands in the supernatant were due to the high concentration of antiserum proteins in the supernatant.

$G S$ activity in $B$. fragilis cell extracts

Crude extracts from $B$. fragilis cells grown under conditions of limiting nitrogen, which induced the presence of GS detected by Western blotting, were assayed for GGT activity. No GGT activity was detected.

Attempts at purification of GS from B. fragilis cell extracts by differential PEG precipitation and gel filtration (Southern et al., 1986), which had proved successful for the purification of the cloned GS, did not yield active GS. It was not possible to purify GS from washed or osmotically shocked $B$. fragilis cells.

\section{Inhibition of cloned B. fragilis GS by $B$. fragilis cell extracts}

The effect of $B$. fragilis cell extracts on the GGT activity of cloned $B$. fragilis GS from $E$. coli and $E$. coli GS was investigated (Table 2). The GGT activity of the cloned $B$. fragilis GS from 


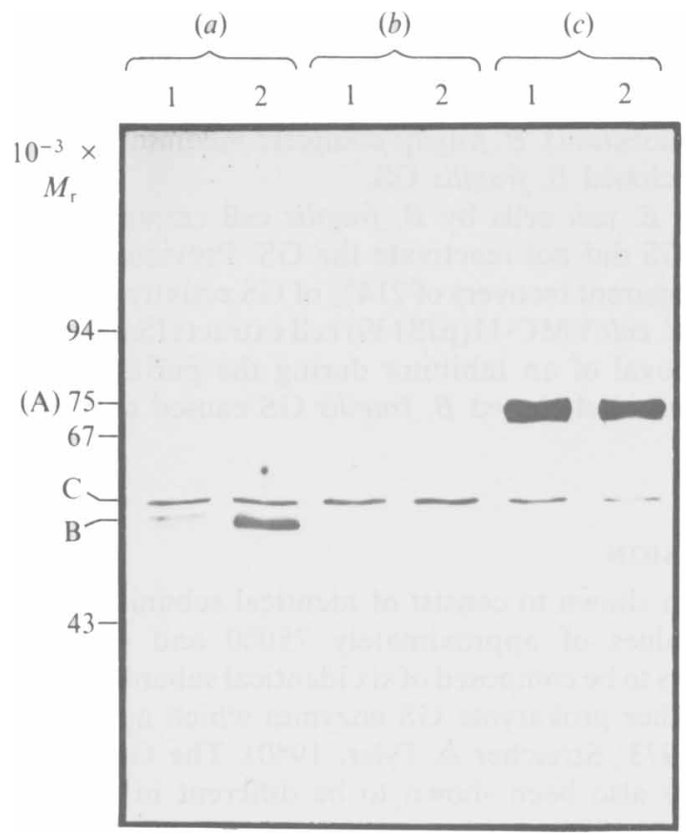

Fig. 7

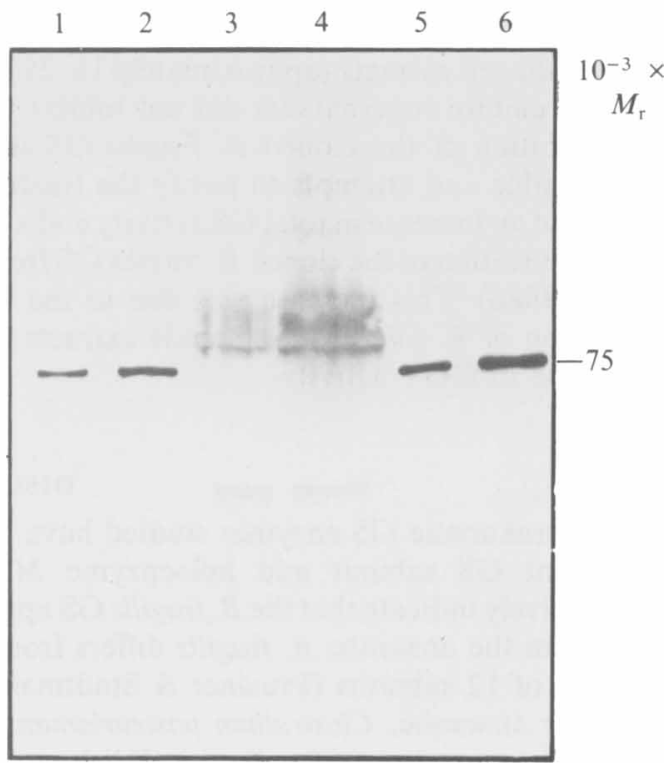

Fig. 8

Fig. 7. Western blot of crude extracts from $E$. coli $\mathrm{YMC}^{-10} \mathrm{Gln} \mathrm{A}^{+} \mathrm{NtrB}^{+} \mathrm{NtrC}^{+}($a), $E$. coli $\mathrm{YMC}-11$ Gln $\mathrm{A}^{-} \mathrm{NtrB}^{-} \mathrm{NtrC}^{-}(b)$ and $E$. coli YMC-11(pJS139) (c) cells. The SDS-PAGE-fractionated proteins were transferred to nitrocellulose paper and reacted initially with antiserum prepared against purified samples of the cloned $B$. fragilis GS. This reaction only revealed the bands with apparent $M_{\mathrm{r}}$ values of approximately $75000(\mathrm{~A})$. Subsequent reaction of the blot with an antiserum prepared against purified samples of $V$. alginolyticus GS, which cross-reacts with $E$. coli GS (B), revealed the other bands (C). $E$. coli YMC-10, crude extracts from nitrogen-limited (lane 1,30 $\mu \mathrm{g}$ protein) and -repressed (lane 2 , $30 \mu \mathrm{g}$ protein) cells. E. coli YMC-11, crude extracts from nitrogen-limited (lane 1, $30 \mu \mathrm{g}$ protein) and -repressed (lane 2, $30 \mu \mathrm{g}$ protein) cells. $E$. coli YMC-11(pJS139), crude extracts from nitrogen-limited (lane $1,5 \mu \mathrm{g}$ protein) and -repressed (lane $2,5 \mu \mathrm{g}$ protein) cells.

Fig. 8. Western blots of a partially purified preparation of the cloned B. fragilis GS from $E$. coli before and after immunoprecipitation with antiserum prepared against purified samples of the cloned $B$. fragilis GS. Lanes 1 and 2, active partially purified GS ( 1 and $2 \mu$ grotein respectively); lanes 3 and 4 , supernatant after immunoprecipitation of 1 and $2 \mu \mathrm{g}$ partially purified GS protein respectively; lanes 5 and 6 , immunoprecipitates corresponding to the preparations in lanes 3 and 4 respectively.

\section{Table 2. Inhibition of cloned B. fragilis $G S$ from $E$. coli by $B$. fragilis cell extracts}

GGT activities are expressed as a percentage of the activity of untreated cell extracts [2.03 and 0.85 $\mu \mathrm{mol} \gamma$-glutamyl hydroxamate formed (mg protein $)^{-1} \mathrm{~min}^{-1}$ for cloned GS and $E$. coli GS respectively]. SEM values were $5-10 \%$ of the values in the Table.

GS

Inhibitor

Cloned GS

E. coli GS

$$
\begin{aligned}
& \text { Inhibitor } \\
& \text { protein concn } \\
& \left(\mathrm{mg} \mathrm{ml}^{-1}\right)
\end{aligned}
$$

GGT activity
$(\%)$
100
8
8
17
91
95
100
75
84

* B. fragilis cell extracts. 
E. coli YMC-11(pJS139) was inhibited by $>90 \%$ by dialysed and non-dialysed crude extracts from $B$. fragilis cells. Boiled $B$. fragilis cell extracts inhibited the cloned GS by $>80 \%$. In contrast, GS from $E$. coli YMC-10 cells was not markedly affected by dialysed and non-dialysed $B$. fragilis cell extracts (approximately $16-25 \%$ inhibition). $B$. fragilis complete medium and $B$. fragilis culture supernatants did not inhibit the cloned $B$. fragilis GS.

Inhibition of the cloned $B$. fragilis GS from $E$. coli cells by $B$. fragilis cell extracts was irreversible and attempts to purify the treated GS did not reactivate the GS. Previously, we reported an increase in total GS activity and an apparent recovery of $214 \%$ of GS activity during the purification of the cloned B. fragilis GS from E. coli YMC-11(pJS139) cell extracts (Southern et al., 1986). This increase was due to the removal of an inhibitor during the purification. Addition of $E$. coli YMC-11 crude extracts to purified cloned B. fragilis GS caused an $80 \%$ decrease in GGT activity.

\section{DISCUSSION}

All prokaryote GS enzymes studied have been shown to consist of identical subunits. The apparent GS subunit and holoenzyme $M_{\mathrm{r}}$ values of approximately 75000 and 490000 respectively indicate that the $B$. fragilis GS appears to be composed of six identical subunits. The GS from the anaerobe $B$. fragilis differs from other prokaryote GS enzymes which normally consist of 12 subunits (Prusiner \& Stadtman, 1973; Streicher \& Tyler, 1980). The GS from another anaerobe, Clostridium pasteurianum, has also been shown to be different in that it appears to consist of 20 subunits (Krishnan et al., 1986).

$\mathrm{NH}_{4}^{+}$-shocking of crude cell extracts containing the cloned $B$. fragilis GS resulted in a loss of GGT activity which was not due to a shift in the $\mathrm{pH}$ optimum and an isoactivity point could not be determined. In E. coli the optimum $\mathrm{pH}$ for the GGT assay is $\mathrm{pH} 6.9$ for shocked preparations and 7.9 for unshocked preparations (Stadtman \& Ginsburg, 1974). A NH-dependent increase in GGT activity and the inability to determine an isoactivity point has been reported for Rhodopseudomonas palustris (Alef \& Zumft, 1981), Rhodospirillum rubrum (Falk et al., 1982), Chloroflexus aurantiacus (Kaulen \& Klemme, 1983), and V. alginolyticus (Bodasing et al., 1985).

The GS enzymes from Gram-negative bacteria have been shown to be covalently modified by adenylylation, whereas there is no evidence for GS regulation by adenylylation in Gram-positive bacteria (Tronick et al., 1973; Wolhueter et al., 1973). Alteration of GS activity by SVP treatment is utilized as presumptive evidence for regulation by the adenylylation-deadenylylation system (Stadtman et al., 1970). GGT activity of adenylylated or $\mathrm{NH}_{4}^{+}$-shocked E. coli GS measured in the presence of $0.3 \mathrm{mM}-\mathrm{Mn}^{2+}$ is unchanged after SVP treatment, whereas activity in the presence both of $0.3 \mathrm{~mm}-\mathrm{Mn}^{2+}$ and of $60 \mathrm{mM}-\mathrm{Mg}^{2+}$ is greatly increased. There is no change in the GGT activity of GS from the Gram-positive bacteria Bacillus subtilis (Schreier et al., 1985), C. pasteurianum (Kleiner, 1979) and Clostridium acetobutylicum (Usdin et al., 1986) and the archaebacterium Methanobacterium ivanovi (Bhatnagar et al., 1986) in the presence of $\mathrm{Mn}^{2+}$ or $\mathrm{Mg}^{2+}$ or $\mathrm{Mn}^{2+}$ plus $\mathrm{Mg}^{2+}$. In contrast, SVP treatment of the cloned B. fragilis GS resulted in the inactivation of GS from $\mathrm{NH}_{4}^{+}$-shocked and unshocked cells and $\mathrm{Mn}^{2+}$ and $\mathrm{Mg}^{2+}$ did not affect this inactivation by SVP. The activity of the cloned $B$. fragilis GS is not inhibited by AMP, whereas in other bacteria AMP acts as a feedback inhibitor of GS (Deuel \& Prusiner, 1974). In most Gram-negative bacteria the GS is subjected to the adenylylation control mechanism and is less affected by feedback inhibitors than GS from Gram-positive bacteria. The cloned $B$. fragilis GS appears to be sensitive to feedback inhibition by amino acids. Arginine, histidine, alanine, glutamic acid and glycine inhibited GGT activity significantly $(>20 \%)$.

The sensitivity of the cloned $B$. fragilis GS to SVP and the apparent lack of adenylylation in $E$. coli cells is interesting since $E$. coli is known to adenylylate other cloned GS genes from Gramnegative bacteria. The Anabaena GS cloned in $E$. coli is also not subject to adenylylation (Fisher et al., 1981).

In $E$. coli and other Gram-negative bacteria the addition of $\mathrm{Mg}^{2+}$ to $\mathrm{NH}_{4}^{+}$-shocked or unshocked cells increased or inhibited the GGT activity respectively. The GGT activity of the 
cloned $B$. fragilis $\mathrm{GS}$ from $\mathrm{NH}_{4}^{+}$-shocked or unshocked cell extracts was inhibited to the same extent by $\mathrm{Mg}^{2+}$. It is interesting that the GS from another anaerobe, C. acetobutylicum, was also inhibited by $\mathrm{Mg}^{2+}$ (Usdin et al., 1986). The marked stimulation in GGT activity of the cloned GS from $\mathrm{NH}_{4}^{+}$-shocked cells by low concentrations of $\mathrm{Mn}^{2+}(0.25 \mathrm{mM})$ appears to be a unique feature of the cloned $B$. fragilis GS. GGT activity of the cloned $B$. fragilis and the $E$. coli GS (Stadtman \& Ginsburg, 1974) was inactivated by $>0.5 \mathrm{mM}-\mathrm{Mn}^{2+}$.

Western blotting indicated that the $B$. fragilis $g \ln A$ gene appeared to be cloned on pJS139 and similar GS subunits were produced in E. coli YMC-11(pJS139) and B. fragilis. Previously, we showed that GS production by the cloned $B$. fragilis $g \ln A$ gene in $E$. coli was regulated by nitrogen. Although it was not possible to assay GS activity in $B$. fragilis cell extracts, Western blotting indicated that GS production was regulated by nitrogen.

The importance of GS for ammonia incorporation into amino acids in $B$. fragilis has been questioned (Yamamoto et al., 1985). A problem in assessing the role of GS in B. fragilis is the inability to assay the enzyme in $B$. fragilis cell extracts. We have shown that the lack of GGT activity in $B$. fragilis cell extracts is not due to very low levels of enzyme but is the result of the inactivation of the GS by $B$. fragilis cell extracts. This inactivation appears to be relatively specific since $E$. coli $G S$ was not inactivated to the same extent. The relatively small amount of inactivation of the $E$. coli GS by $B$. fragilis cell extract was presumably due to feedback inhibition. The inactivation of the cloned $B$. fragilis GS by $B$. fragilis cell extracts was irreversible, but is unlikely to involve an enzyme reaction as boiled cell extracts inhibited the GS.

\section{REFERENCES}

AlEF, K. \& ZuMFT, W. G. (1981). Regulatory properties of glutamine synthetase from the nitrogen-fixing phototrophic bacterium Rhodopseudomonas palustris. Zeitschrift für Naturforschung 38c, 784-789.

Backman, K., Chen, Y.-M. \& Magasanik, B. (1981). Physical and genetic characterization of the $g \ln A$ $\operatorname{gln} G$ region of the Escherichia coli chromosome. Proceedings of the National Academy of Sciences of the United States of America 78, 3743-3747.

Bender, R. A., Janssen, K. A., Resnick, A. D., Blumenberg, M., FoOR, F. \& Magasanik, B. (1977). Biochemical parameters of glutamine synthetase from Klebsiella aerogenes. Journal of Bacteriology 129, 1001-1009.

Bhatnagar, L., Zeikus, J. G. \& Aubert, J.-P. (1986). Purification and characterization of glutamine synthetase from the archaebacterium Methanobacterium ivanovi. Journal of Bacteriology 165, 638-643.

Bodasing, S. J., Brandt, P. W., RobB, F. T. \& Woods, D. R. (1985). Purification and regulation of glutamine synthetase in a collagenolytic Vibrio alginolyticus strain. Archives of Microbiology 140, 369-374.

BRADFORD, M. M. (1976). A rapid and sensitive method for the quantitation of microgram quantities of protein utilizing the principle of protein-dye binding. Analytical Biochemistry 72, 248-254.

DAVIS, R. W., Botstein, D. \& RoTH, J. R. (1980). Advanced Bacterial Genetics. Cold Spring Harbor, New York: Cold Spring Harbor Laboratory.

Deuel, T. F. \& Prusiner, S. (1974). Regulation of glutamine synthetase from Bacillus subtilis by divalent cations, feedback inhibitors and L-glutamine. Journal of Biological Chemistry 249, 257-264.

Falk, G., Johansson, B. C. \& Norlund, S. (1982). The role of glutamine synthetase in the regulation of nitrogenase activity (switch off effect) in Rhodospirillum rubrum. Archives of Microbiology 132, 251-253.
Fisher, R., Tuli, R. \& HaselkoRn, R. (1981). A cloned cyanobacterial gene for glutamine synthetase functions in Escherichia coli, but the enzyme is not adenylylated. Proceedings of the National Academy of Sciences of the United States of America 78, 33933397.

Frey, T. D., EISENBERG, D. \& EISERLING, F. A. (1975). Glutamine synthetase forms three- and sevenstranded cables. Proceedings of the National Academy of Sciences of the United States of America 72, 34023406.

Holdeman, L. V. \& Moore, W. E. C. (1972). Anaerobe Laboratory Manual. Blacksberg, USA: Virginia Polytechnic Institute and State University.

Johnson, D. A., Gautsch, J. W., Sportsman, J. R. \& ELDER, J. H. (1984). Improved technique utilizing nonfat dry milk for analysis of proteins and nucleic acids transferred to nitrocellulose. Genetic Analytical Techniques 1, 3-8.

Kaulen, H. \& Klemme, J. H. (1983). No evidence of covalent modification of glutamine synthetase in the thermophilic phototrophic bacterium Chloroflexus aurantiacus. FEMS Microbiology Letters 20 , 75-79.

KLEINER, D. (1979). Regulation of ammonium uptake and metabolism by nitrogen fixing bacteria. III. Clostridium pasteurianum. Archives of Microbiology 120, 263-270.

Krishnan, I. S., Singhal, R. K. \& Dua, R. D. (1986). Purification and characterization of glutamine synthetase from Clostridium pasteurianum. Biochemistry 25, 1589-1599.

LAEMMLI, U. K. (1970). Cleavage of structural proteins during the assembly of the head of bacteriophage T4. Nature, London 227, 680-685.

ManaraJ, R., RobB, F. T. \& Woods, D. R. (1986). Temperature and oxygen regulated expression of a glutamine synthetase gene from Vibrio alginolyticus 
cloned in Escherichia coli. Archives of Microbiology 146, 30-34.

MEISTER, A. (1980). Catalytic mechanism of glutamine synthetase, overview of glutamine metabolism. In Glutamine Metabolism, Enzymology and Regulation, pp. 1-40. Edited by J. Mora and R. Palacios. New York: Academic Press.

Miller, J. H. (1972). Experiments in Molecular Genetics. Cold Spring Harbor, New York: Cold Spring Harbor Laboratory.

Mossie, K. G. M., Jones, D. T., RobB, F. T. \& Woods, D. R. (1979). Characterization and mode of action of a bacteriocin produced by a Bacteroides fragilis strain. Antimicrobial Agents and Chemotherapy 16, 724-730.

O'FARREL, P. H. (1985). High resolution two-dimensional electrophoresis of proteins. Journal of Biological Chemistry 250, 4007-4021.

Prusiner, S. \& Stadtman, E. R. (Editors) (1973). The Enzymes of Glutamine Metabolism. New York: Academic Press.

RYBICKI, E. P. \& VON WEChMAR, M. B. (1982). Enzyme assisted immune detection of plant virus proteins electroblotted onto nitrocellulose paper. Journal of Virological Methods 5, 267-278.

SCHREIER, H. J., Fisher, S. H. \& Sonenshein, A. L. (1985). Regulation of expression from the $\operatorname{gln} A$ promoter of Bacillus subtilis requires the glnA gene product. Proceedings of the National Academy of Sciences of the United States of America 82, 33753379.

Southern, J. A., KatZ, W. \& WoOds, D. R. (1984). Purification and properties of a cell-bound bacteriocin from a Bacteroides fragilis strain. Antimicrobial Agents and Chemotherapy 25, 253-257.

Southern, J. A., Parker, J. R. \& Woods, D. R. (1986). Expression and purification of glutamine synthetase from Bacteroides fragilis. Journal of General Microbiology 132, 2827-2835.
Stadtman, E. R. \& Ginsburg, A. (1974). The glutamine synthetase of Escherichia coli, structure and control. In The Enzymes, vol. 10, pp.755-807. Edited by P. S. Boyer. New York: Academic Press. Stadtman, E. R., Ginsburg, J. E., Ciardi, J. E., Yeh, J., Henning, S. B. \& Shapiro, B. M. (1970). Multiple molecular forms of glutamine synthetase produced by enzyme catalysed adenylylation and deadenylylation reactions. Advances in Enzyme Regulation 8, 99-118.

Streicher, S. L. \& TYler, B. (1980). Purification of glutamine synthetase from a variety of bacteria. Journal of Bacteriology 142, 69-78.

Towbin, H., Staehelin, T. \& Gordon, J. (1979). Electrophoretic transfer of proteins from polyacrylamide gels to nitrocellulose sheets: procedure and some applications. Proceedings of the National Academy of Sciences of the United States of America 76, 4350-4354.

Tronick, S. R., Ciardi, J. E. \& Stadtman, E. R. (1973). Comparative biochemical and immunological studies of bacterial glutamine synthetases. Journal of Bacteriology 115, 858-868.

USDIN, K. P., ZAPPE, H., JONES, D. T. \& WoODS, D. R. (1986). Cloning, expression, and purification of glutamine synthetase from Clostridium acetobutylicum. Applied and Environmental Microbiology 52, 413-419.

VAREL, J. M. \& BRYANT, M. P. (1974). Nutritional features of Bacteroides fragilis subspecies fragilis. Applied Microbiology 18, 251-257.

WOLHEUTER, R. M., SchuTt, H. \& Holzer, H. (1973). Regulation of glutamine synthetase in vivo in E. coli. In The Enzymes of Glutamine Metabolism, pp.45-66. Edited by S. Prusiner \& E. R. Stadtman. New York: Academic Press.

Yамамото, I., AвE, A., SaIto, H. \& Ishimoto, M. (1984). The pathway of ammonia assimilation in Bacteroides fragilis. Journal of General and Applied Microbiology 30, 499-508. 